\title{
The effects of blending dimethyl ether with LPG on the engine operation and its efficiency
}

\begin{abstract}
The paper presents a continuation of a research program related to the activators for gaseous fuels used in modern vehicles. Selected vehicle dynamic parameters obtained by the application of a mixture of LPG and DME for the mass share of 0 to $26 \%$ have been presented. The object of the research was a 1.6 SI engine adapted to a combustion of gaseous fuels. The authors present the results of the energy conversion efficiency in a four cylinder $S I 1.6 \mathrm{~cm}^{3}$ engine.
\end{abstract}

Keywords: alternative fuels, DME, LPG, fuel blend, SI engine, combustion

\section{Wpływ udziału DME na przebieg spalania mieszaniny DME-LPG w silniku ZI}

\begin{abstract}
Artykut prezentuje wybrane wyniki badań nad aktywatorami spalania alternatywnych paliw gazowych, wykorzystywanych do napędu pojazdów samochodowych. Określono wplyw udziatu DME w mieszaninie DME-LPG na sprawność przetwarzania energii w silniku ZI. Obiektem badań byt czterocylindrowy silnik napędzający samochód Opel Astra, wyposażony $w$ dodatkowy uktad zasilania, typu PFI. W badaniach wykorzystano mieszaniny DME-LPG o udziale masowym DME od 0 do $26 \%$. Dla każdej z mieszanin zrealizowano kilka serii pomiarowych, w ustalonych warunkach pracy silnika. Wyjaśniono wpływ udziału DME w mieszaninie na osiagi silnika, a także podstawowe parametry charakteryzujace proces spalania. Stwierdzono, że masowy udziat DME nieprzekraczajacy $11 \%$ wptywa na zwiększenie sprawności przetworzenia energii, przyrost ciśnienia, stopień wypalenia ładunku i ilość wydzielanego ciepła.

Słowa kluczowe: paliwa alternatywne, DME, LPG, mieszanina paliw, silnik ZI, spalanie
\end{abstract}

\section{Introduction}

An increasing interest in the application of DME as an alternative fuel for vehicle engine propulsion results from multiple production possibilities, including different sources such as natural gas, carbon, biomass as well as black liquor from the pulp mill. Due to a high cetane number of DME the main research programs carried out by different centers concentrate on the application of DME in CI engines. However, taking into consideration the fact that physicochemical properties of DME are similar to LPG, it can be blended with LPG and applied as a fuel for heating devices and gas engine based generators and heat pumps $[1,2]$. The ease of LPG and DME blending and using this mixture either as an additive or substitute for pure LPG opens an opportunity of diversification of the fuel sources together with an increasing energy security. Currently approximately $80 \%$ of manufactured DME is added to LPG as a mixture of $20 / 80 \%$. [3]. DME applied as an additive allowing an accelerate the start of combustion in many internal combustion engines including CI, CCCI and HCCI $[4,5]$. A research on SI engines powered by a blend of DME and n-butane has been carried out by Lee $\mathrm{S}$. that aims at estimating the engine operation characteristics and exhaust gas composition [6,7]. The results of the research pointed to the significant influence of the lower calorific value of DME on the engine torque and power output as well as on the fuel consumption, thus confirming the conclusions formulated by the authors on the basis of the research carried out in the Transport Department of Silesian University of Technology [8]. Chin G., together

\section{Wprowadzenie}

Wzrost zainteresowania eterem dimetylowym - DME, jako paliwem alternatywnym do napędu pojazdów samochodowych jest przede wszystkim spowodowany możliwością jego wytwarzania $\mathrm{z}$ wielu źródeł, takich jak gaz ziemny, węgiel, biomasa, a także ług czarny, czyli półpłynny, wysokoenergetyczny produkt uboczny w przemyśle celulozowym. Ponieważ DME cechuje wysoka liczba cetanowa większość prowadzonych obecnie prac badawczo-rozwojowych i wdrożeniowych dotyczy jego wykorzystania do zasilania silników ZS. Mając jednak na uwadze fakt, iż własności fizykochemiczne DME są podobne do LPG, jest on również mieszany z LPG i używany, jako paliwo dla urządzeń grzewczych oraz silników gazowych napędzających generatory i pompy ciepła $[1,2]$. Łatwość mieszania LPG i DME i wykorzystania tej mieszaniny, jako suplementu lub też zamiast LPG, sprzyja zarówno dywersyfikacji paliw jak i zwiększeniu bezpieczeństwa energetycznego. Obecnie ponad $80 \%$ produkowanego na świecie DME dodaje się do LPG, wytwarzając mieszaninę tych paliw, w proporcji 20/80 \% [3].

DME jest wykorzystywane również, jako dodatek przyspieszający rozpalanie wielu paliw zasilających silniki ZS, dwupaliwowe, CCCI oraz HCCI [4, 5]. Badania silnika ZI zasilanego mieszaniną DME i n-butanu przeprowadził Lee S., wyznaczając jego charakterystyki zewnętrzne i określając emisję składników toksycznych spalin [6, 7]. Wyniki tych badań wykazały znaczny wpływ niższej wartości opałowej DME na rozwijany przez silnik moment obrotowy i zużycie paliwa, potwierdzając wnioski sformułowane na podstawie 
with his team in 2011 carried out a research on an SI stationary engine used for micro-cogeneration purposes. The engine was fed with LPG and DME mixtures of a DME mass share varying from 5 to $40 \%$ [9]. The obtained results enabled a development of combustion control algorithms, particularly with respect to knock detection.

Delaying the spark ignition timing and variation of the air-fuel ratio enables the engine operation without knocking for blends up to $25 \%$ of DME.

The exhaust gas have a high concentration of DME and formaldehyde as well as of NMHCs (non-methane hydrocarbons) that can, however, be easily reduced by a conventional exhaust aftertreatment system.

Among many factors that spurred the authors on to start the research on the application of di-methyl ether as a fuel for SI engines the most important was a significant feature of $\mathrm{DME}$ - the ability of influencing the shortening of the onset time of the combustion of the air-fuel mixture (combustion process activator). High burning speed of DME speeds up the onset of the combustion of the LPG-DME mixture similarly as hydrogen added to natural gas (Fig. 1). This paper presents the test stand results carried out on an Opel Astra vehicle whose engine was fueled with LPG and DME blends of the mass ratios varying from 5 to $26 \%$.

\section{Properties of the tested fuel}

Selected chemical and physical properties, of gaseous fuels have been listed in Table 1. Fuels featuring low boiling temperature are Methane and Hydrogen, while the boiling temperature of the DME does not vary much when related to hydrocarbons that constitute the crude oil based gases. High Cetane number of DME enables its application in CI engines. The density of DME as well as of crude oil based gases is similar both in the gaseous and liquid phases, while its low pressure allows storing it in the liquid phase in ambient temperatures. A theoretical air demand for DME is the lowest among all the gaseous fuels, which results from the

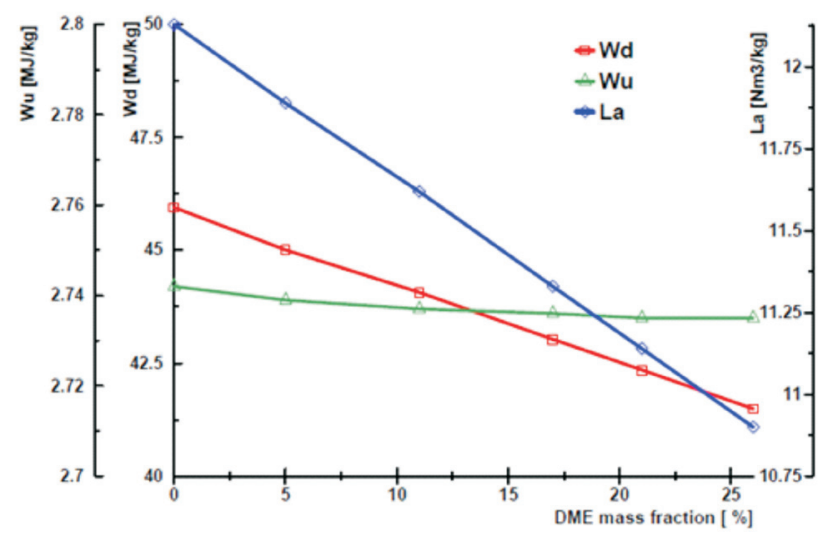

Fig. 2. Mass heating value as a function of DME mass ratio, $\mathrm{Wu}-\mathrm{Mass}$ heating value of a stoichiometric mixture, $\mathrm{Wd}$ - Mass heating value of fuel, La - stoichiometric air to fuel ratio

Rys. 2. Wartość opałowa mieszaniny w zależności od udziału DME,

$W u$ - wartość opałowa mieszanki stechiometrycznej; Wd-wartość opałowa paliwa; La-zapotrzebowanie powietrza dla stechiometrycznej mieszaniny paliw badań symulacyjnych, przeprowadzonych na Wydziale Transportu Pol. Śl. [8]. Chin G., wraz ze swoim zespołem przeprowadził w roku 2011 badania stacjonarnego silnika ZI, przeznaczonego dla systemu mikrokogeneracji, zasilając go mieszaninami LPG i DME, o udziale masowym DME w zakresie od 5 do $40 \%$ [9]. Uzyskane wyniki umożliwiły opracowanie algorytmów sterowania procesem spalania,

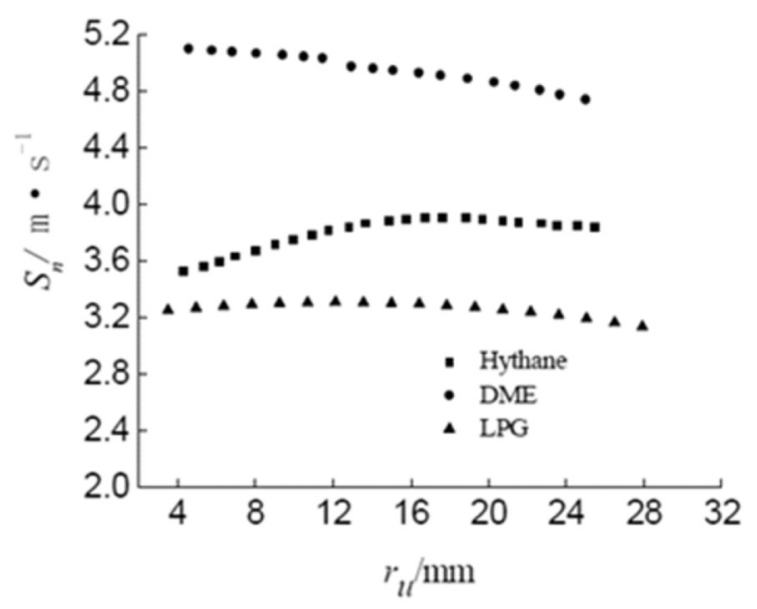

Fig. 1. Flame speed versus radius for Hythane ${ }^{\circledR}$, DME and LPG [11] Rys. 1. Szybkość spalania gazu ziemnego wzbogaconego wodorem, DME i LPG w zależności od promienia rozprzestrzeniającego się płomienia [11]

przede wszystkim w zakresie kontroli spalania detonacyjnego oraz wykazały, że:

- opóźnienie zapłonu i zmiana współczynnika nadmiaru powietrza zapewnia pracę silnika bez spalania stukowego, gdy jest on zasilany mieszaninami zawierającymi do $25 \%$ DME,

- w spalinach silnika występuje duża koncentracja DME i formaldehydu, a także węglowodorów NMHC, które są redukowane poprzez wykorzystanie standardowego układu oczyszczania spalin.

Wśród wielu czynników, które skłoniły autorów niniejszego opracowania do podjęcia prac nad wykorzystaniem eteru dwumetylowego do zasilania silników ZI należy wyróżnić jego bardzo istotną cechę, wpływającą na skrócenie czasu rozpalania mieszaniny powietrzno-gazowej, dlatego paliwo to można umownie nazwać aktywatorem procesu spalania. Duża prędkość spalania DME przyspiesza inicjację spalania mieszaniny LPG i DME, podobnie jak wodór $\mathrm{W}$ mieszaninie $\mathrm{z}$ gazem ziemnym (rys. 1). W niniejszym opracowaniu zaprezentowano wyniki badań stanowiskowych przeprowadzonych przy wykorzystaniu samochodu Opel Astra, którego silnik zasilano mieszaninami LPG i DME o udziale masowym DME w zakresie od 5 do $26 \%$.

\section{Charakterystyka paliwa wykorzystanego w badaniach}

Wybrane właściwości fizyko-chemiczne paliw gazowych scharakteryzowano w tabeli 1. Paliwami o niskiej tempe- 
oxygen content in the fuel. As a result, the calorific value of the air-fuel mixture, in the case of DME-LPG blend remains constant even with the increasing mass share of DME (Fig. 2).

Mixtures used in the research program were prepared on a special stand. They were blended in an appropriate sequence and stored in a tank positioned on an electronic scale (Fig. 3). For the purpose of the presented research 5 different mixtures were prepared of the composition as follows (mass shares):

- $5 \%$ DME, $95 \%$ LPG,

- $11 \%$ DME, $89 \%$ LPG,

- $17 \%$ DME, $83 \%$ LPG,

$-21 \%$ DME, $79 \%$ LPG,

$-26 \%$ DME, $74 \%$ LPG.

The research also provided a test for a propane-butane fuel blend respectively (40/60). The prepared fuels were loaded at $500 \mathrm{kPa}$ to a properly configured feed system operating as an additional equipment of the tested vehicle. Through an injection rail, the system delivered vaporized gas mixtures directly to the intake manifold ducts. The electronic injection system was set up to form a stoichiometric mixture, while the fuel excess coefficient was calculated according to the following formula:

$$
\lambda=\frac{\mathrm{m}_{\text {air }}}{\mathrm{m}_{\mathrm{LPG}} \cdot \mathrm{AFR}_{\mathrm{LPG}_{\text {stoich. }}}+\mathrm{m}_{\mathrm{DME}} \cdot \mathrm{AFR}_{\mathrm{DME}_{\text {stoich. }}}}
$$

Similar ignition temperatures and combustion speeds guarantee good combustibility of the prepared mixtures while providing comparable energy conversion efficiency in the tested engine.

Table 1. Characteristic of the selected alternative fuels [14]

Tabela 1. Właściwości wybranych paliw alternatywnych [14]

\begin{tabular}{|l|c|c|c|c|c|}
\hline Specification & $\mathrm{DME}$ & $\mathrm{n}$-Butane & Propane & Methane & Hydrogen \\
\hline Chemical structure & $\mathrm{CH}_{3} \mathrm{OCH}_{3}$ & $\mathrm{C}_{4} \mathrm{H}_{10}$ & $\mathrm{C}_{3} \mathrm{H}_{8}$ & $\mathrm{CH}_{4}$ & $\mathrm{H}_{2}$ \\
\hline Molecular weight, $\mathrm{g} / \mathrm{mol}$ & 46,07 & 58,12 & 44,09 & 16,4 & 2,02 \\
\hline Liquid density, $\mathrm{kg} / \mathrm{m}^{3}$ & 661 & 578 & 500 & 415 & 71 \\
\hline Boiling point, ${ }^{\circ} \mathrm{C}$ & $-24,9$ & $-0,5$ & -42 & -162 & $-252,9$ \\
\hline Octane number & - & 92 & 105 & 130 & 130 \\
\hline Cetane number & $55-60$ & 10 & 5 & - & - \\
\hline Mass heating value, $\mathrm{MJ} / \mathrm{kg}$ & 28,8 & 45,72 & 46,30 & 50,20 & 121,0 \\
\hline Stoichiometric $\mathrm{A} / \mathrm{F}, \mathrm{kg} / \mathrm{kg}$ & 9,0 & 15,46 & 15,88 & 17,2 & 34,2 \\
\hline Ignition temperature, ${ }^{\circ} \mathrm{C}$ & 350 & 405 & 470 & $540-650$ & 400 \\
\hline Burning vclocity, $\mathrm{cm} / \mathrm{s}$ & 50 & 41 & 45,0 & $30-33-8$ & $\min .271$ \\
\hline Wobbe index, $\mathrm{MJ} / \mathrm{m}^{3}$ & 52 & 91 & 81 & 54 & 48 \\
\hline c/h/o & $52 / 13 / 35$ & $83 / 17 / 0$ & $82 / 18 / 0$ & $75 / 25 / 0$ & $0 / 100 / 0$ \\
\hline
\end{tabular}

\section{Measurement set-up}

The tested object was an Opel Astra fitted with a 1600 $\mathrm{cm}^{3}$ engine, adapted to alternative fuel propulsion. The main features characterizing the engine installed in the tested vehicle have been listed in Table 2. The engine performance has been estimated on the basis of acquired dynamic raturze wrzenia są metan i wodór, natomiast temperatura wrzenia DME nie odbiega znacznie od wartości temperatury dla węglowodorów zawartych w mieszaninie gazów ropopochodnych. Wysoka liczba cetanowa DME zapewnia jego wykorzystanie do zasilania silników ZS. Gęstość DME i gazów ropopochodnych jest podobna zarówno w fazie skroplonej jak i lotnej, a niewielkie ciśnienie pozwala na jego magazynowanie w fazie skroplonej w temperaturze otoczenia. Teoretyczne zapotrzebowanie powietrza dla DME jest najniższe spośród wszystkich paliw gazowych, co wynika z zawartego w nim tlenu. W konsekwencji wartość opałowa dostarczanej do silnika mieszanki powietrza i DME wraz z LPG jest stała, pomimo wzrastającego udziału masowego DME (rys. 2).

Do badań przygotowano mieszaniny wytworzone na specjalnym stanowisku, mieszając LPG, o zawartości $40 \%$ propanu i $60 \%$ butanu z DME, w ściśle określonej kolejności i magazynując je następnie w zbiorniku umieszczonym na wadze tensometrycznej (rys. 3). Wykorzystano mieszaniny o następujących udziałach masowych:

- $5 \%$ DME, $95 \%$ LPG,

- $11 \%$ DME, $89 \%$ LPG,

- $17 \%$ DME, $83 \%$ LPG,

$-21 \%$ DME, $79 \%$ LPG,

- $26 \%$ DME, $74 \%$ LPG.

Tak przygotowane mieszaniny, wprowadzano pod ciśnieniem $500 \mathrm{kPa}$, do odpowiednio skonfigurowanego dodatkowego układu zasilania. Układ ten dostarczał odparowaną mieszaninę gazów do kanałów dolotowych badanego silnika, poprzez magistralę wtryskową. System sterowania dawką wtryskiwanej mieszaniny zapewniał uzyskanie mieszanki stechiometrycznej, przy czym współczynnik nadmiaru powietrza obliczano z zależności (1).

Zbliżone wartości temperatury zapłonu i szybkości spalania zapewniają dobre własności palne wytworzonych mieszanek i porównywalną sprawność przetwarzania energii w badanym silniku.

\section{Obiekt badań i stanowisko badaweze}

Obiektem prowadzonych badań był samochód OPEL Astra napędzany silnikiem ZI o pojemności $1600 \mathrm{~cm}^{3}$, przy-

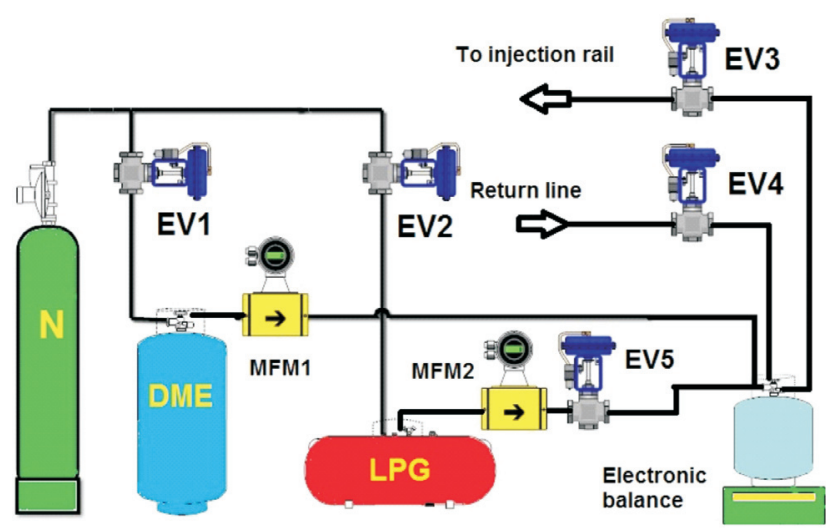

Fig. 3. LPG and DME blends preparation stand (EV - electrovalve, MFM mass flow meter)

Rys. 3. Układ przygotowania mieszaniny LPG i DME 
characteristics defining the power on the wheels as a function of vehicle speed.

The characteristics of the prepared fuels were acquired on a BOSCH FLA 203 chassis dynamometer for different DME content. A simplified test stand diagram have been presented in Fig. 4.

The test stand has been equipped with various transducers and sensors allowing an identification of the engine operating conditions. The basic measurement and control systems allowed a continuous acquisition of the engine operating conditions through the recording of:

- In-cylinder pressures, crankshaft angle with TDC identification,

- Power on the wheels, manifold pressure, intake air temperature,

- Exhaust gas temperature,

- Fuel mass flow to the engine.

The in-cylinder pressure was measured with the piezoelectric pressure transducer (type 6121) coupled with the 5011 charge amplifier - both KISTLER type. The measurement of the crankshaft angle and its speed was realized with the help of a crankshaft position sensor (type 2613B by KISTLER).

Additional measurements included the recording of

Table 2. Engine specifications

Tabela 2. Charakterystyka obiektu badań

\begin{tabular}{|l|c|}
\hline Cylinder number and layout & $4 \mathrm{R}$ \\
\hline Maximum power & $55 \mathrm{~kW} @ 5200 \mathrm{rpm}$ \\
\hline Maximum torque & $128 \mathrm{~N} \cdot \mathrm{m} @ 2800 \mathrm{rpm}$ \\
\hline Displacement & $1598 \mathrm{ccm}$ \\
\hline Bore x stroke & $79.0 \times 81.5 \mathrm{~mm}$ \\
\hline Compression ratio & 9.6 \\
\hline
\end{tabular}

the manifold pressure. The fuel mass flow to the fuel feed system of the tested engine was recorded with the use of an electronic scale.

All parameters were acquired and visualized with the use of a data acquisition card (type NI PCI-6143) and were further processed with the help of a script debugged in the LabView 7.1 environment.

The research has been developed according to the predefined program covering:

- The estimation of power on the wheels of the tested vehicle as a function of the vehicle speed for all of the tested DME-LPG blends,

- The estimation of the in-cylinder pressure as a function of the crankshaft angle,

- The identification of specific fuel consumption.

The research covering the engine indication and specific fuel consumption were carried at idle and for WOT at the engine speeds of 1500, 2000, 2500 and $35001 / \mathrm{min}$ for each of the prepared blends.

During the tests no modifications in the engine control were done. The ignition timing was set up for the operation on

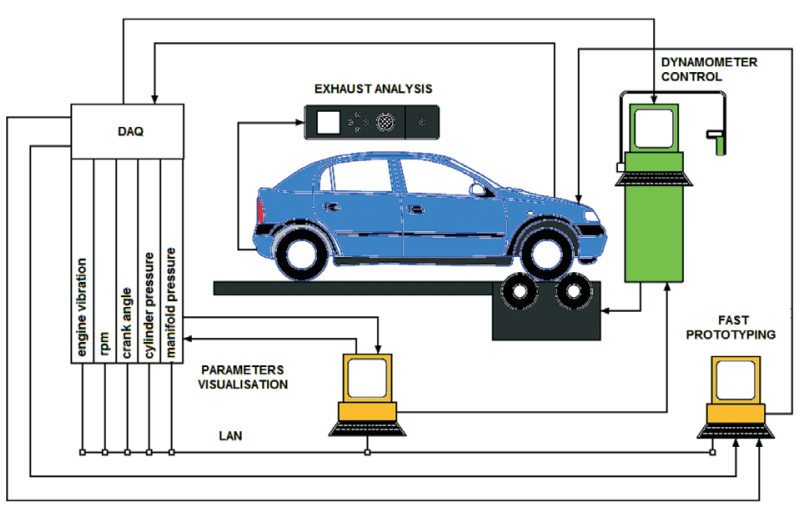

Fig. 4. Diagram of the test stand [12]

Rys. 4. Schemat stanowiska badawczego [12]

stosowanym do zasilania alternatywnego paliwem gazowym. Zasadnicze parametry charakteryzujące silnik badanego samochodu przedstawia tabela 2 .

Osiągi samochodu określono analizując jego charakterystyki dynamiczne, wyrażające zależność mocy rozwijanej na kołach od prędkości samochodu. Charakterystyki te uzyskano za pomocą hamowni podwoziowej firmy Bosch typu FLA 203, dla przygotowanych wcześniej mieszanin, o różnym udziale masowym DME. Uproszczony schemat stanowiska przedstawiono na rysunku 4.

Stanowisko badawcze wyposażono również w przetworniki i czujniki zapewniające identyfikację stanu pracy silnika. Podstawowe układy kontrolno-pomiarowe, zapewniały ciągłą rejestrację stanu pracy silnika, poprzez pomiar:

- ciśnienia w cylindrach silnika,

- kąta obrotu wału korbowego wraz z określeniem GMP tłoka,

- mocy rozwijanej na kołach badanego samochodu,

- podciśnienia panującego w kolektorze dolotowym,

- temperatury powietrza dolotowego i spalin,

- strumienia masy paliwa gazowego dostarczanego do silnika.

Ciśnienie wewnątrz cylindra mierzono wykorzystując piezoelektryczny czujnik ciśnienia typu 6121 oraz wzmacniacz ładunku typu 5011 firmy KISTLER. Położenie wału korbowego oraz jego prędkość obrotową określano za pomocą znacznika położenia wału korbowego typu 2613B firmy KISTLER.

Dodatkowo mierzono i rejestrowano sygnał przetwornika ciśnienia absolutnego w kolektorze dolotowym silnika. Strumień masy paliwa gazowego dopływającego do układu zasilania silnika mierzono za pomocą precyzyjnej wagi tensometrycznej.

Wszystkie parametry rejestrowano i wizualizowano za pomocą karty akwizycji danych NI PCI-6143, a następnie przetwarzano za pomocą programu opracowanego w środowisku LabView 7.1.

\section{Metodyka badań}

Badania przeprowadzono zgodnie $\mathrm{z}$ ustalonym programem, który obejmował:

- określenie mocy na kołach badanego samochodu w zależności od jego prędkości przy zasilaniu silnika przygotowanymi mieszaninami DME i LPG, 
gasoline, while stoichiometric air fuel ratio was continuously controlled in a closed loop mode by means of the ECU responsible for gas fuel dosage. The EGR valve remained closed.

\section{Research methodology}

The research has been developed according to the predefined program that covered:

- The estimation of power on the wheels of the tested vehicle as a function of the vehicle speed for all of the tested DME-LPG blends,

- The estimation of the in-cylinder pressure as a function of the crankshaft angle,

- The identification of specific fuel consumption.

The research covering the engine indication and specific fuel consumption were carried at idle and for WOT at the engine speeds of 1500, 2000, 2500 and $35001 / \mathrm{min}$ for each of the prepared blends. During the tests no modifications in the engine control were done. The ignition timing was set up for the operation on gasoline, while stoichiometric air fuel ratio was continuously controlled in a closed loop mode by means of the ECU responsible for gas fuel dosage. The EGR valve remained closed.

\section{Results and discussion}

\section{Vehicle performance}

The engine power and torque results for the operation on various mixtures are listed in Table 3 and their courses as a function of the engine speed are presented in Fig. 5.

Table 3. Power and torque of the tested engine

Tabela 3. Maksymalne wartości mocy i momentu obrotowego badanego silnika

\begin{tabular}{|c|c|c|c|c|c|}
\hline & $\begin{array}{l}\text { DME and LPG } \\
\text { mass ratio }\end{array}$ & $\begin{array}{c}\text { Max. Power } \\
{[\mathrm{kW}]}\end{array}$ & $\begin{array}{c}\text { Engine rpm } \\
{\left[\mathrm{min}^{-1}\right]}\end{array}$ & $\begin{array}{c}\text { Max. Torque } \\
\text { [Nm] }\end{array}$ & $\begin{array}{c}\text { Engine } \mathrm{rpm}_{\mathrm{M}} \\
\quad\left[\min ^{-1}\right]\end{array}$ \\
\hline 1 & $\mathbf{5} \%$ DME, $95 \%$ LPG & 59,5 & 4772 & 140 & 2720 \\
\hline 2 & $\begin{array}{c}11 \% \text { DME, } 89 \% \\
\text { LPG }\end{array}$ & 59,6 & 5001 & 141 & 2640 \\
\hline 3 & $\begin{array}{c}17 \% \mathrm{DME}, 83 \% \\
\text { LPG }\end{array}$ & 59,1 & 5001 & 135,2 & 2899 \\
\hline 4 & $\begin{array}{c}21 \% \text { DME, } 79 \% \\
\text { LPG }\end{array}$ & 57,4 & 5210 & 128,2 & 3208 \\
\hline 5 & $\begin{array}{c}26 \% \text { DME, } 74 \% \\
\text { LPG }\end{array}$ & 58,2 & 5350 & 125,4 & 2800 \\
\hline 6 & $100 \%$ LPG & 59,2 & 5071 & 134,8 & 2670 \\
\hline
\end{tabular}

The DME share in the mixture influences the engine power and torque, however, the maximum differences in the torque can be noticed in the range between 1000 and 3500 $\mathrm{rpm}$. The variations of the course of power remain stable for the speeds from 1000 to $4500 \mathrm{rpm}$. The maximum engine power output has been recorded for $5001 \mathrm{rpm}$, for the mixture featuring $11 \% \mathrm{DME}$, while maximum torque equaling $141 \mathrm{~N} \cdot \mathrm{m}$ has been registered at $2640 \mathrm{rpm}$. In the case of DME enriched LPG, with the share not exceeding $17 \%$, a small torque increase has been noticed, together with comparable tested engine power outputs. Increasing the DME share above $17 \%$ results in a drop of both the power and the torque as compared to a propane-butane mixture.
- określenie przebiegu ciśnienia w zależności od kąta obrotu wału korbowego,

- określenie masowego zużycia paliwa.

Badania obejmujące indykowanie silnika i pomiar zużywanego paliwa przeprowadzono na biegu jałowym oraz przy maksymalnym obciążeniu silnika dla prędkości obrotowych 1500, 2000, 2500, 3000 i 3500 1/min, dla każdej z przygotowanych mieszanin.

W czasie badań nastawy regulacyjne silnika nie były korygowane. Kąt wyprzedzenia zapłonu ustalany był przez sterownik zarządzający nim w czasie pracy na benzynie, natomiast stechiometryczny skład każdej mieszanki ustalano i kontrolowano za pomocą sterownika zarządzającego dawką paliwa gazowego. Zawór EGR w czasie badań był zamknięty.

\section{Analiza wyników badań}

\section{Osiągi samochodu}

Wyniki pomiarów mocy i momentu obrotowego rozwijanego przez silnik samochodu, który zasilano mieszaninami o różnym udziale masowym DME zestawiono w tabeli 3, a przebieg zmian mocy i momentu obrotowego w zależności od prędkości obrotowej silnika przedstawiono na rysunku 5.

Udział DME w mieszaninie wpływa na zmianę mocy $\mathrm{i}$ momentu silnika, przy czym największe różnice w przebiegu momentu występują w zakresie prędkości obrotowych silnika od 1000 do 3500 1/min. Przebieg zmian mocy osiąganej przez silnik jest natomiast równomierny w zakresie prędkości obrotowych od 1000 do 4500 obr/min. Najwyższą wartość mocy maksymalnej, równą 59,6 kW uzyskano przy $\mathrm{n}=5001 \mathrm{obr} / \mathrm{min}$, dla mieszaniny zawierającej $11 \% \mathrm{DME}$, najwyższą wartość momentu obrotowego równą $141 \mathrm{~N} \cdot \mathrm{m}$ przy $\mathrm{n}=2640 \mathrm{obr} / \mathrm{min}$. W przypadku LPG wzbogaconego udziałem DME nieprzekraczającym 17 \%, zaobserwowano nieznaczny wzrost wartości momentu obrotowego i porównywalne wartości mocy rozwijanej przez silnik badanego samochodu. Wzrost udziału DME powyżej $17 \%$ powoduje obniżenie mocy i momentu obrotowego $\mathrm{w}$ porównaniu $\mathrm{z}$ mieszaniną propanu i butanu.

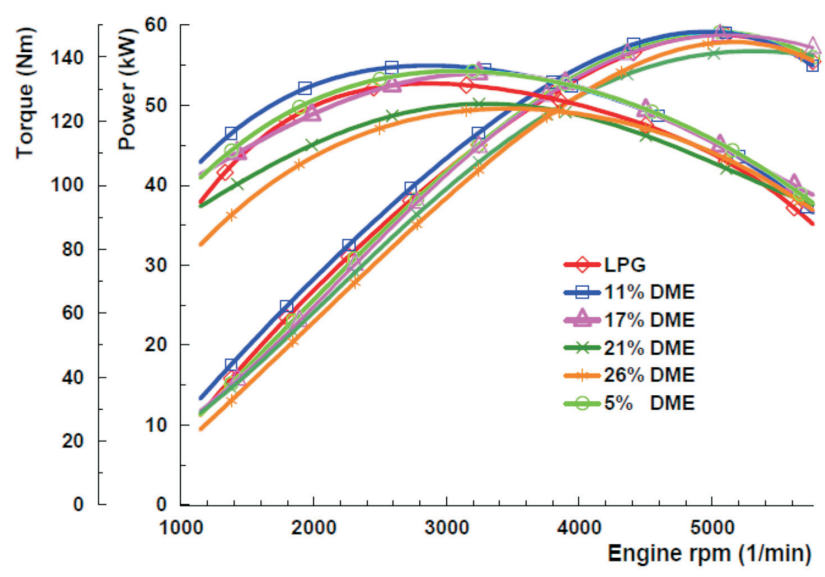

Fig. 5. Performance characteristics of the engine powered by all of the prepared fuels

Rys. 5. Charakterystyki zewnętrzne badanego silnika w zależności od rodzaju zastosowanego paliwa 


\section{Transformations inside engine cylinder}

On the basis of the data stored during the dyno-tests, a numerical analysis has been carried out with the application of a mathematical model permitting the observations of thermodynamic processes in the cylinder of the tested engine. The model completes additional calculations on the basis of the registered indicated pressure courses solving the energy balance equations for a closed combustion chamber [13].

The diagrams presented below show the influence of the DME share in the mixture on the courses of basic indexes describing the combustion process in the tested engine.

The averaged pressure courses for the subsequent 200 operation cycles of the engine for full load at $3000 \mathrm{rpm}$ have been presented in Fig. 6, while the IMEP for all the mixtures have been presented in Fig. 7. The DME-LPG blends insignificantly increased the peak and the mean pressure values despite the fact that the engine speed and ignition timing remained unchanged. The stability of the combustion process, described by COV_IMEP does not exceed $2.5 \%$ for the mixtures with the DME shares up to $17 \%$ while for higher amounts of DME it reaches $4 \%$.

Figure 6 presents the cylinder pressure in the case of blends with different DME fractions. In the case of the LPG-DME blend stoichiometric mixture combustion, an early growing in-cylinder pressure and a higher value of the peak pressure have been observed but only in the case of mixtures that did not exceed $17 \%$ of the DME share. With the increase of the DME fraction above $17 \%$ the cylinder pressure curve rise retarded and the peak pressure crankshaft angle was delayed leading to a decrease of the peak cylinder pressure along with the increasing DME fraction in the blends. Although the flame propagation speed rises with the increase of the DME fraction in the blends, the retardation in the optimum ignition timing with the increase of the DME fraction still delays the rise of the cylinder pressure. In addition, the constant heating value of the blend with an increase of the DME fraction without the correction of the

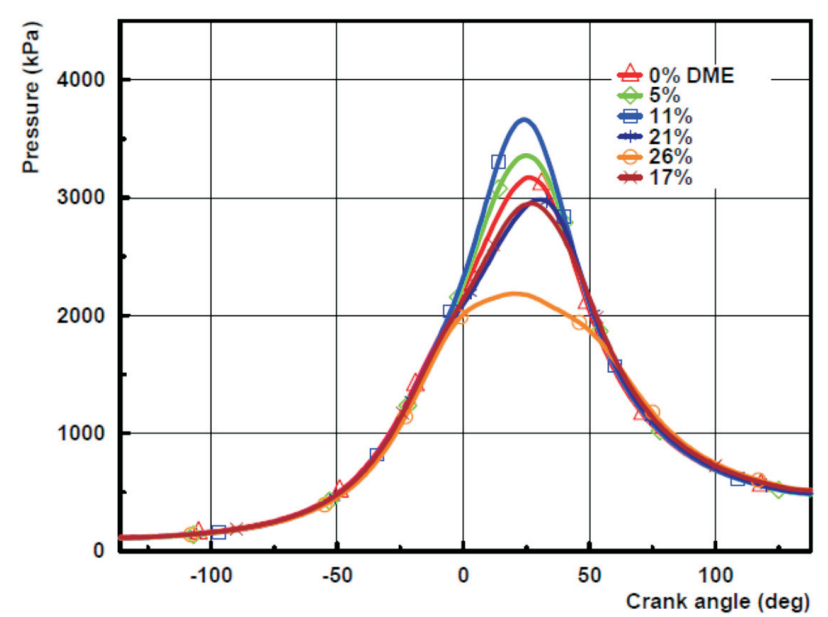

Fig. 6. Mean cylinder pressure as a function of crankshaft angle for all tested fuels, $\mathrm{n}=3000 \mathrm{rpm}$, WOT

Rys. 6. Uśrednione przebiegi zmian ciśnienia dla badanych mieszanin, przy prędkości $3000 \mathrm{l} / \mathrm{min}$ i petnym obcią̇eniu silnika

\section{Przemiany zachodzące w cylindrze}

Na podstawie wyników pomiarów zarejestrowanych podczas testów na hamowni podwoziowej przeprowadzono obliczenia symulacyjne $\mathrm{z}$ wykorzystaniem modelu matematycznego analizującego przemiany termodynamiczne zachodzące w cylindrze silnika. Wykorzystywany model dokonuje obliczeń uzupełniających w oparciu o zarejestrowany przebieg zmian ciśnienia indykowanego rozwiązując układ równań bilansu energii w zamkniętej komorze spalania [13].

Prezentowane poniżej wykresy przedstawiają wpływ udziału DME w paliwie na przebiegi podstawowych wielkości opisujących proces spalania w badanym silniku.

Uśrednione przebiegi ciśnienia dla 200 kolejnych cykli roboczych silnika, przy pełnym obciążeniu silnika i prędkości $3000 \mathrm{obr} / \mathrm{min}$ przedstawiono na rysunku 6, natomiast wartości średniego ciśnienia indykowanego (IMEP) uzyskanego dla wszystkich mieszanin na rysunku 7. Mieszaniny DME i LPG zwiększyły nieznacznie wartości ciśnień maksymalnych i średnich pomimo tego, że prędkość obrotowa silnika, jego obciążenie i kąt wyprzedzenia zapłonu pozostawały niezmienne.

Stabilność spalania, którą określono za pomocą COV_IMEP nie przekracza 2,5\% dla mieszanin zawierających do $17 \%$ DME i $4 \%$ dla mieszanin o udziale przekraczającym $17 \%$.

Spalanie mieszanek stechiometrycznych zapewnia wcześniejsze uzyskanie maksymalnej wartości ciśnienia, ale tylko dla mieszanin, w których udział DME nie przekracza 17 \%. Udziały masowe DME przekraczające 17 \% zwiększają wartości kąta obrotu wału korbowego, przy których występują maksymalne wartości ciśnień oraz przyczyniają się do zmniejszenia ich wartości. Pomimo faktu, iż prędkość rozprzestrzeniania się płomienia zwiększa się wraz ze wzrostem udziału DME w mieszaninie przyrost ciśnienia wewnątrz cylindra wydłuża się w czasie dla mieszanin zawierających ponad $17 \%$ DME. Ponadto, stała wartość opałowa mieszanki pomimo wzrastającego udziału DME nie zapewnia utrzymania wartości ciśnienia maksymalnego na zbliżonym poziomie.

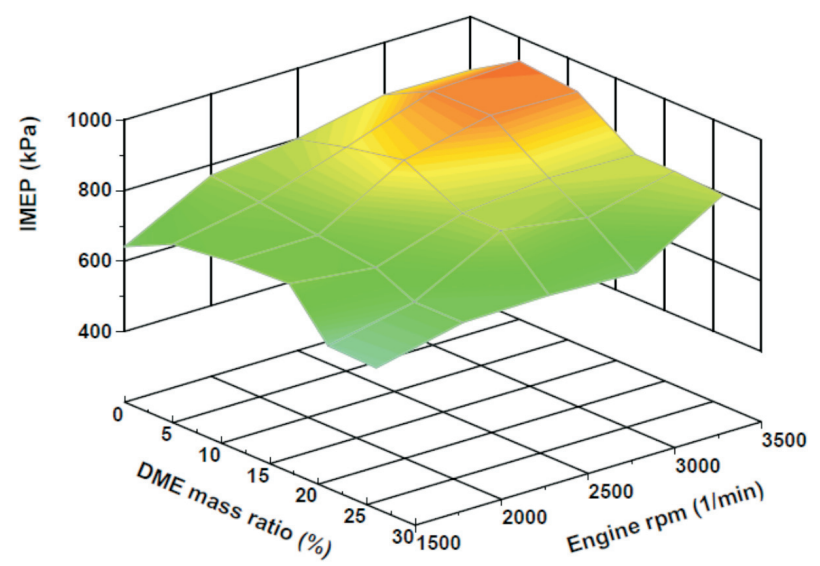

Fig. 7. The influence of the DME fraction and engine rpm on the IMEP Rys. 7. Wptyw udziału DME i prędkości obrotowej silnika na IMEP przy petnym obciązeniu silnika 
ignition angle lowers the peak value of the cylinder pressure. Lower ignition energy and temperature of DME is also the main reason for reaching of the maximum pressure values that are close to TDC. The DME mass share in the mixture, however, has a significant influence on the crankshaft angle at which the pressure reaches its maximum value. For the mixtures featuring 5 and $11 \%$ DME content the maximum pressure was obtained faster than in the case of the LPG fuel feed. The influence of the DME content on the pressure increase rate $\mathrm{dp} / \mathrm{d} \alpha$ has been presented in Fig. 8 .

Higher pressure increase rates were obtained for mixtures featuring 5 and $11 \%$ of the DME content and were higher when compared to the results obtained for LPG. An increasing share of DME caused a lowering of the pressure increase rates.

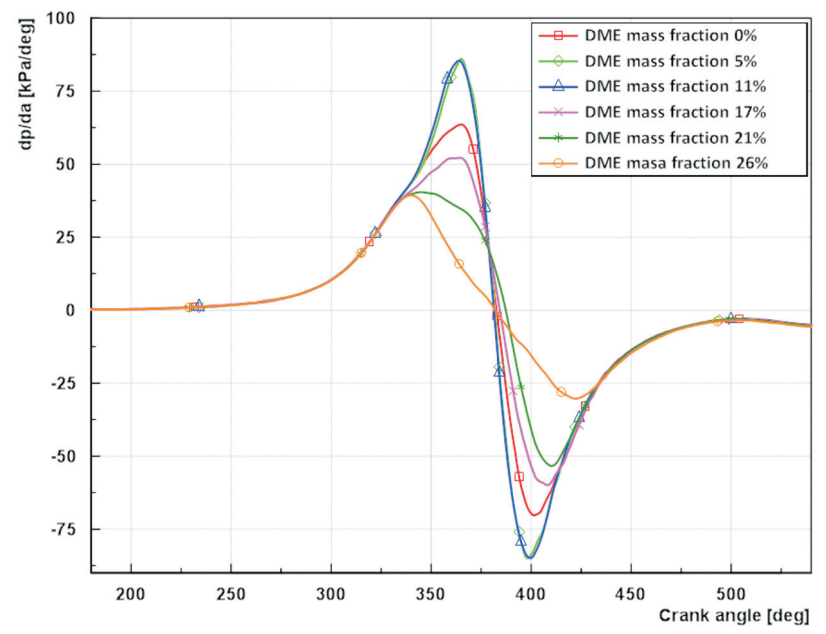

Fig. 8. Course of $\mathrm{dp} / \mathrm{d} \alpha$ for all blends, $\mathrm{n}=30001 / \mathrm{min}$, WOT

Rys. 8. Przyrost ciśnienia w zależności od prędkości obrotowej, udziału DME przy petnym obciążeniu silnika

Figure 9 shows the maximum mean gas temperature versus the DME fraction. The maximum mean gas temperature increases slightly with the increase of the DME fraction in the blend but only to $11 \%$. Next, a slight drop in the maximum mean gas temperature is presented when the DME fraction exceeds $11 \%$. The improvement in the combustion rate tends to increase the gas temperature.

Figure 10 shows the heat release rate of the blends with different DME fractions. Similarly to the cylinder pressure tracings for stoichiometric mixture combustion, the fastest heat release rate and the highest value of the maximum heat release rate were recorded for the blend with the $11 \% \mathrm{DME}$ content. A further increase in the DME fraction over $11 \%$ resulted in a decrease of the maximum heat release rate.

On the basis of the charge combustion ratio, presented in Fig. 11 it can be observed that mixtures featuring the DME shares of 5 and $11 \%$ not only initiate the combustion faster but also the dynamics of their combustion is higher than it is in the case of LPG. For those mixtures the combustion duration is also shorter, while the DME share rising over the $11 \%$ retards the onset of combustion and prolongs the very process. This tendency is characteristic of the entire range of engine speeds.
Mniejsza energia i temperatura zapłonu DME stanowią również zasadniczy powód uzyskania maksymalnej wartości ciśnienia bliżej GMP. Ponadto udział masowy DME w mieszaninie ma decydujący wpływ na wartość kata obrotu wału korbowego, przy którym ciśnienie osiąga wartość maksymalną. Dla mieszanin zawierających 5 i $11 \%$ ciśnienie maksymalne zostało osiągnięte wcześniej niż w przypadku, gdy silnik zasilano wyłącznie LPG. Wpływ zawartości DME na przyrost ciśnienia dp/d $\alpha$ przedstawiono na rysunku 8 .

Najwyższe wartości przyrostu ciśnienia uzyskano dla mieszanin zawierających 5 i $11 \%$ DME i były one wyższe od wartości uzyskanej dla LPG. Zwiększający się udział DME zmniejszał jednak wartości przyrostów ciśnienia.

Wpływ udziału DME w mieszaninie na wartości temperatury maksymalnej wewnątrz cylindra przedstawiono

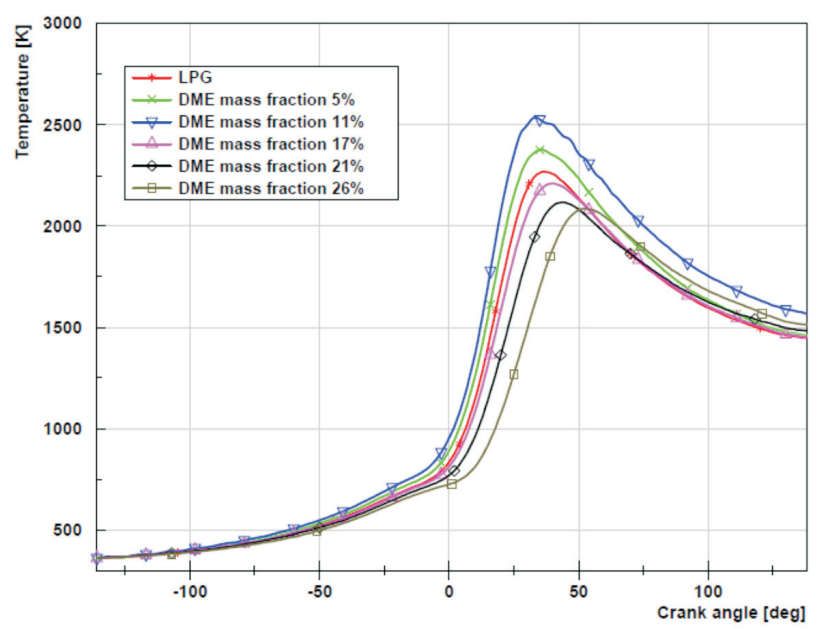

Fig. 9. The courses of in-cylinder temperatures for all blends, @ $\mathrm{n}=30001 / \mathrm{min}$ and WOT

Rys. 9. Temperatury $w$ cylindrze przy petnym obciażeniu i $\mathrm{n}=3000 \mathrm{obr} / \mathrm{min}$

na rysunku 9. Średnia wartość temperatury maksymalnej wzrasta nieznacznie wraz ze wzrostem udziału DME do $11 \%$, dalszy wzrost udziału DME powoduje zmniejszenie wartości uśrednionych temperatur maksymalnych. Ponadto zwiększenie przyrostu temperatury skutkuje jej wyższymi wartościami maksymalnymi.

Przebiegi wywiązywania się ciepła dla badanych mieszanin przedstawiono na rysunku 10 . Zmiany te przebiegają podobnie do zmian ciśnienia, tym samym największą wartość współczynnika wywiązywania się ciepła uzyskano dla mieszaniny zawierającej $11 \%$ DME. Zwiększanie udziału DME powyżej $11 \%$ zmniejsza szybkość wydzielania ciepła.

Na podstawie analizy zmian stopnia wypalenia masy ładunku (rys. 11), można zauważyć, że mieszaniny o udziale 5 i $11 \%$ DME nie tylko szybciej się rozpalają, ale również dynamika ich spalania jest większa niż w przypadku LPG. Dla mieszanin tych krótszy jest również czas spalania. Wzrost udziału DME powyżej $11 \%$ opóźnia rozpalenie mieszanin i wydłuża czas ich spalania. Tendencja ta jest charakterystyczna dla całego zakresu prędkości obrotowych badanego silnika. 
Figure 12 presents the course of the overall efficiency estimated on the basis of the power delivered with the fuel and related to the power on the wheels. The overall efficiency values have been averaged for all of the measurement points obtained for defined DME shares in the mixture and for different engine speeds at WOT.

The highest overall efficiency values were obtained for the mixtures featuring the DME share from 5 to $11 \%$. In this range the DME share allowed obtaining of a higher ef-

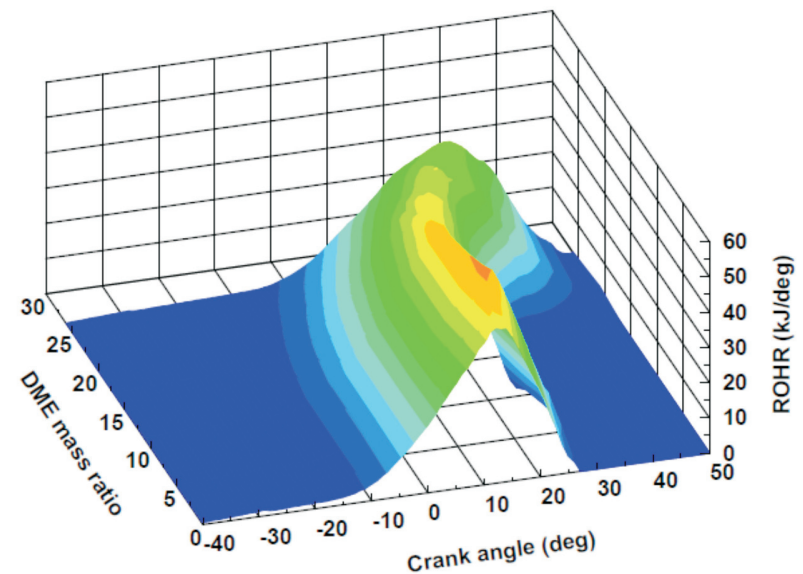

Fig. 10. ROHR as a function of rpm and DME ratio

Rys. 10. Współczynnik wywiązywania się ciepła w funkcji prędkości obrotowej i udziału DME

ficiency than in the case of LPG fueling. The increase in the DME content in the blends over $11 \%$ caused a slight drop in the overall efficiency.

$\mathrm{HC}$ emissions of the tested engine have been presented in Fig. 13. Due to the fact that the engine fuel consisted of LPG and DME, the amount of emitted hydrocarbons grew slightly with the increasing share of DME as compared to the emissions recorded for LPG. The increase, excluding the case of $5 \%$ DME mixture, is stable and the maximum emission of hydrocarbons for the blend of $26 \%$ DME does not exceed $220 \mathrm{ppm}$. The characteristics of the $\mathrm{HC}$ emission

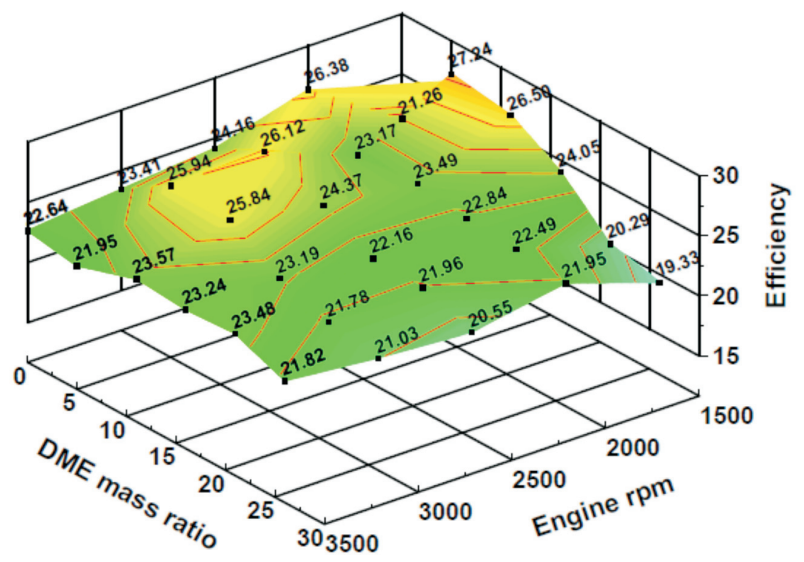

Fig. 12. Engine efficiency, mean values for all measurements points Rys. 12. Sprawność ogólna, uśredniona dla wszystkich punktów pomiarowych
Na rysunku 12 przestawiono przebieg zmian sprawności ogólnej, którą wyznaczono na podstawie mocy dostarczonej wraz z paliwem i rozwijanej na kołach badanego pojazdu. Wartości sprawności ogólnej uśredniono dla wszystkich punktów pomiarowych, które zrealizowano przy określonym udziale DME w mieszaninie, przy różnych prędkościach obrotowych i całkowitym otwarciu przepustnicy. Najwyższe wartości sprawności ogólnej uzyskano dla mieszanin zawierających od 5 do $11 \%$ DME. W tym zakresie udział DME

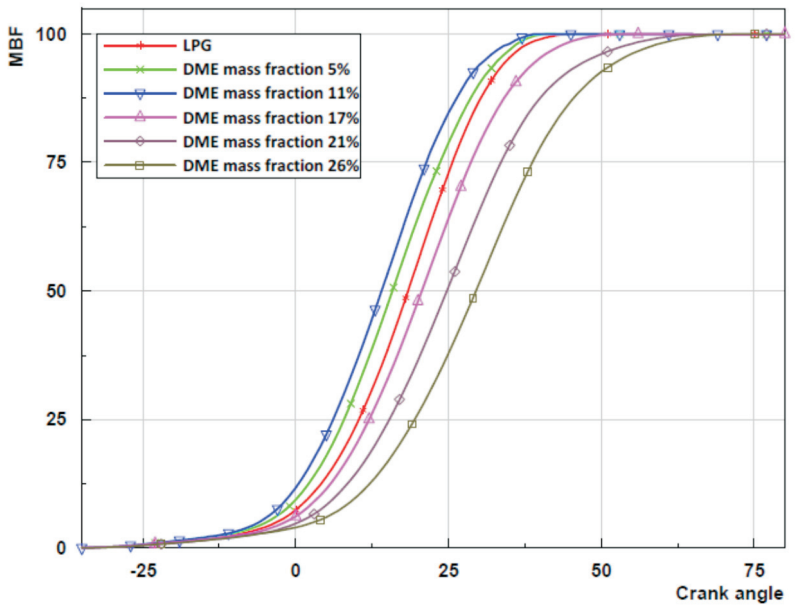

Fig. 11. MFB of all blends, @ engine n=2500 1/min and WOT Rys. 11. Stopień wypalenia tadunku dla badanych mieszanin przy petnym obciążeniu silnika i prędkości $n=2500 \mathrm{obr} / \mathrm{min}$

w mieszaninie zapewniał uzyskanie sprawności wyższej niż uzyskiwana podczas zasilania silnika LPG. Wzrost udziału DME w mieszaninie powyżej $11 \%$ spowodował nieznaczne zmniejszenie sprawność ogólnej.

Emisję $\mathrm{HC}$ w spalinach badanego silnika przedstawiono na rysunku 13. Ponieważ paliwem zasilającym silnik jest mieszanina LPG i DME ilość wyemitowanych węglowodorów zwiększyła się nieznacznie wraz ze wzrostem udziału DME, w porównaniu z emisją dla LPG, Wzrost ten, z wyjątkiem $5 \%$ udziału DME jest równomierny, a największa wartości emisji HC, uzyskana dla $26 \%$ udziału DME nie przekracza $220 \mathrm{ppm}$. Charakter zmian poziomu emisji

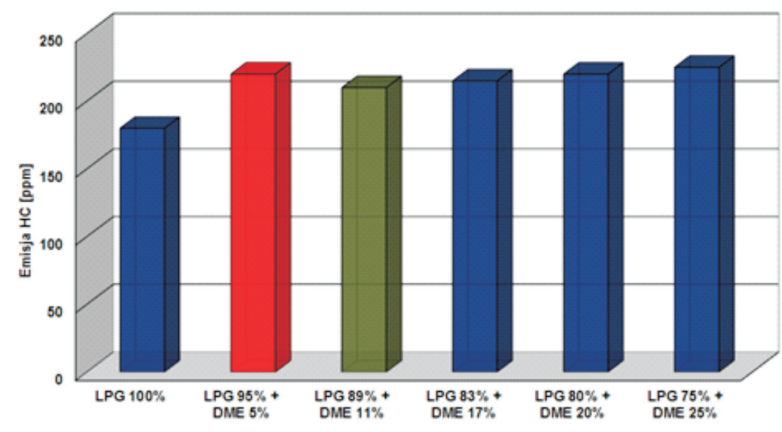

Fig. 13. Total hydrocarbon (THC) emission according to DME content at $\mathrm{n}=20001 / \mathrm{min}$ and WOT

Rys. 13. Emisja HC w zależności od udziału DME w mieszaninie, przy prędkości obrotowej silnika $n=2000 \mathrm{obr} / \mathrm{min}$ 


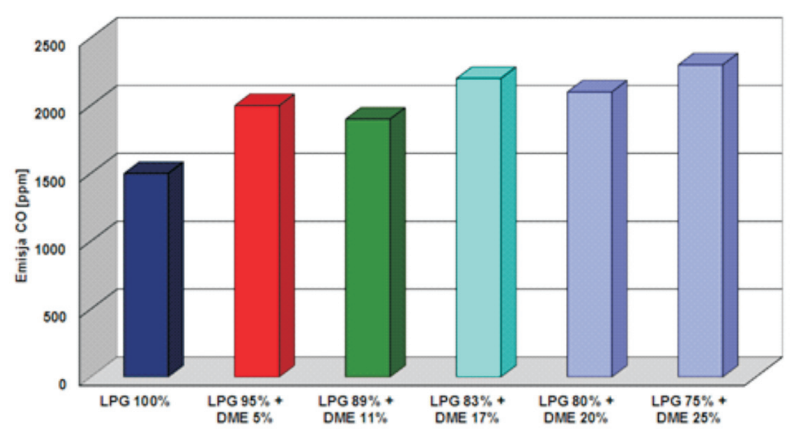

Fig. 14. Carbon monoxide emission according to DME content at engine $\mathrm{n}=20001 / \mathrm{min}$ and WOT

Rys. 14. Emisja CO w zależności od udziału DME w mieszaninie, przy prędkości obrotowej silnika $n=2000 \mathrm{obr} / \mathrm{min}$

variations is similar to $\mathrm{CO}$ whose content in the exhaust gas also increases with the growing DME share in the fuel. The $\mathrm{NO}_{\mathrm{x}}$ emission for the engine speed of $2000 \mathrm{rpm}$ has been presented in Fig. 11. It also rises with the increase of DME in the mixture, mainly due to lower energy and lower ignition temperature. These features influence the earlier onset of the combustion process and higher in-cylinder pressure peak values. For the case of $25 \%$ DME share, the NO emission suddenly drops, which can be connected with knock combustion (due to the settings of the DAQ system these were not recorded during the tests).

\section{Conclusions}

The research covered test-stand investigations of the vehicle fitted with an SI engine fueled with the DME-LPG blends. The authors identified the influence of the DME mass share in the mixture on the overall engine performance, efficiency and the combustion process. It has been observed that:

- Increasing the DME mass share over $11 \%$ results in a reduction of both the engine torque and power output (at factory ignition settings).

- The combustion stability, estimated by mean effective pressure co-variation does not exceed $2.5 \%$ for mixtures featuring the maximum DME share of $17 \%$ and $4 \%$ in the case of blends with more than $17 \%$ of DME.

- The engine factory setup allows an application of DMELPG blends for combustion only if the DME mass share remains below $11 \%$.

The tests carried out on the 4 cylinder SI engine fueled with various DME-LPG blends also enabled an evaluation of different vehicle dynamic characteristics and parameters describing the combustion process in the vehicle engine.

It has been proved that it is possible to obtain results comparable to LPG fueling without any modifications to the engine control system.

The results also prove that a DME-LPG blend does not merely ensure the same engine power output (as compared to exclusive LPG fueling) but increases it. For the case of the DME share not higher than $11 \%$, for the engine operating under full load, the energy transformation efficiency increases. It can therefore be assumed that LPG-DME blend

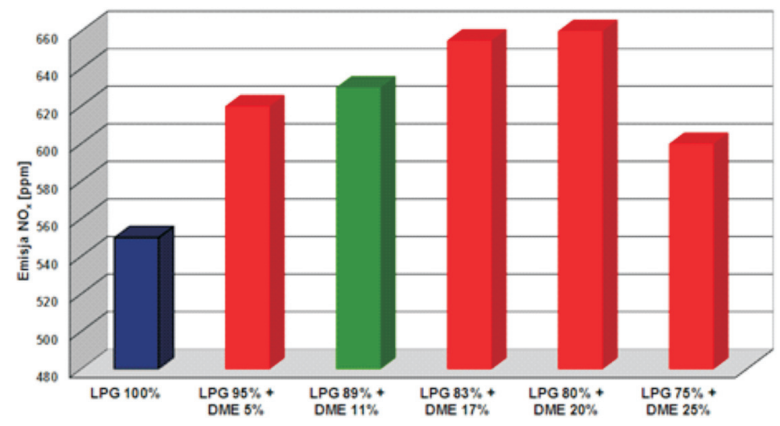

Fig. 15. $\mathrm{NO}_{\mathrm{x}}$ emission according to DME content at engine $\mathrm{n}=20001 / \mathrm{min}$ and WOT

Rys. 15. Emisja $N_{x}$ w zależności od udziału DME w mieszaninie, przy prędkości obrotowej silnika $n=2000 \mathrm{obr} / \mathrm{min}$

HC odpowiada zmianom emisji CO, którego zawartość w spalinach również zwiększa się wraz ze wzrostem udziału DME w mieszaninie dostarczanej do silnika. Emisję $\mathrm{NO}_{\mathrm{x}}$ przy prędkości obrotowej $20001 /$ min przedstawiono na rysunku 15.

Emisja ta wzrasta wraz ze wzrostem udziału DME, a zasadnicze przyczyny tego wzrostu to niższa energia i temperatura zapłonu mieszaniny. Te cechy wpływają na wcześniejsze rozpoczęcie procesu spalania i wyższe wartości maksymalnych ciśnień w cylindrze. Jednak przy $26 \%$ udziale DME w mieszaninie $\mathrm{NO}_{\mathrm{x}}$ ulega nagłemu zmniejszeniu, co może być spowodowane spalaniem stukowym, które w wyniku określonych nastaw aparatury pomiarowej nie zostały zarejestrowane podczas badań.

\section{Wnioski}

Przeprowadzono badania stanowiskowe pojazdu napędzanego silnikiem ZI, zasilając go mieszaninami LPG i DME. Określono wpływ udziału masowego DME w mieszaninie na osiągi pojazdu, silnika, oraz sprawność ogólną i przebieg procesu spalania. Stwierdzono między innymi, że:

- Zwiększenie udziału masowego DME powyżej $11 \%$ powoduje obniżenie rozwijanej przez silnik ZI mocy i momentu obrotowego, przy stałych fabrycznych nastawach regulacyjnych.

- Możliwa jest regulacja przebiegu procesu spalania poprzez zmiany udziału masowego DME w mieszaninie z LPG w funkcji prędkości oborowej.

- Stabilność spalania, określona za pomocą kowariancji średniego ciśnienia nie przekracza 2,5\% dla mieszanin zawierających do $17 \%$ DME i 4,0\% dla mieszanin o udziale przekraczającym $17 \%$.

- Dla fabrycznych nastaw regulacyjnych silnika jest możliwe wykorzystanie mieszanin DME i LPG do napędu pojazdu jedynie w przypadku, gdy udział masowy nie przekracza $11 \%$.

Przeprowadzone badania czterocylindrowego silnika ZI zasilanego mieszaniną LPG i DME o różnym udziale masowym pozwoliły również na określenie charakterystyk dynamicznych samochodu oraz parametrów charakteryzujących proces spalania w napędzającym go silniku. Wykazały, że jest możliwe uzyskanie parametrów porównywalnych z 
definitely has application potential in SI engines. Therefore, it seems necessary to continue the research towards the possible estimation of the optimal engine control settings together with defining a proper map of the air-fuel ratio for the LPG-DME blends.

\section{Nomenclature/Skróty i oznaczenia}

$\mathrm{g}_{\mathrm{e}} \quad$ Specific fuel consumption/jednostkowe zużycie paliwa

CNG Compressed Natural Gas/sprężony gaz ziemny

IMEP Indicated Mean Effective Pressure/średnie ciśnienie indykowane

$\lambda \quad$ Air excess ratio/wspótczynnika nadmiaru powietrza

$\mathrm{Wu} \quad$ Mass heating value of stoichiometric mixture/wartość opałowa mieszanki stechiometrycznej

Wd Mass heating value of fuel/wartość opałowa paliwa

La Stoichiometric air to fuel ratio/stosunek masowy powietrza do paliwa

$\rho \quad$ Density of fuel/gęstość paliwa zasilaniem wyłącznie LPG, bez jakichkolwiek modyfikacji układu zasilania i sterowania procesem spalania.

Wyniki badań wskazują, że w porównaniu z LPG mieszanina LPG i DME pozwala nie tylko na uzyskanie podobnej mocy, ale zapewnia również jej zwiększenie. Dla udziału DME nieprzekraczającego $11 \%$, dla silnika pracującego w warunkach pełnego obciążenia sprawność przetworzenia energii zwiększa się.

Można więc stwierdzić, że mieszanina LPG i DME ma pewien potencjał aplikacyjny w zastosowaniu do silników ZI. Dlatego wydaje się celowym kontynuowanie badań w zakresie ustalenia zarówno optymalnych parametrów regulacyjnych silnika jak i wyznaczenia odpowiedniej wartości współczynnika nadmiaru powietrza mieszanin LPG i DME.

$\mathrm{Pw} \quad$ Wheel power measured/moc na kołach

$\mathrm{T}_{\mathrm{ex}} \quad$ Temperature of exhaust gases at opening exhaust valve/ temperatura gazów wylotowych w momencie otwarcia zaworu

MFB Mass Fraction Burned/stopień wypalenia tadunku

\section{Bibliography/Literatura}

[1] Nakazono T., Raihan K. A., Nishimura A.: A study of application DME-LPG blended fuel to gas engine for micro cogeneration. JSME, 75/751, 2009, p. 504-506.

[2] Nakazono T., Raihan K.A., Nishimura A.: A study of application DME-LPG blended fuel to gas engine for micro cogeneration (2nd Report, Engine Control). JSME, 76/763, 2010, p. 397-399.

[3] AEGPL informacja o mieszaninie DME + LPG.

[4] Sorenson S.C.: Dimethyl ether in diesel engines: Progress and perspectives. J. Eng. Gas Turbines Power, 2001, 123(3), 652-658.

[5] Weidou N., Lijan T., Dewei F.: Rational cognition of DME market in China. Proceedings of 3rd Asian DME conference, 2006, p. 21-38.

[6] Lee S., Oh S., Choi Y.: Performance and emission characteristics of an SI engine operated with DME blended LPG fuel. Fuel 2009; 88(6):1009-1015.

[7] Lee S., Oh S., Choi Y., Kang K.: Effect of n-Butane and propane on performance and emission characteristics of an SI engine operated with DME-blended LPG fuel. Fuel, 90 (2011). p. 1674-1680.

[8] Flekiewicz M., Dykier M.: Studium nad wykorzystaniem mieszaniny DME i gazów ropopochodnych do zasilania silników ZI. Silniki Gazowe - Monografia nr 183. Politechnika Częstochowska, 2010, p. 216-230.

[9] Chin G.T., Chen J.Y., Rap Vi H., Dibble R.W. Development and validation of reduced DME mechanism applicable to various combustion modes in internal combustion engines. Journal of Combustion. Volume 2011, Article ID 630580. p. 1-8.

Marek Flekiewicz, DEng. - doctor in the Faculty of Transport at Silesian University of Technology. Dr inż. Marek Flekiewicz - adiunkt na Wydziale Transportu Politechniki Śląskiej.

e-mail: marek.flekiewicz@polsl.pl
[10] Flekiewicz M.: Wykorzystanie DME do napędu pojazdów samochodowych. Czysta Energia nr 114, 2011.

[11] Wu Xiaomin, Gao Zhongquan, Pi Min, Meng Xiangwen: Investigation of hythane, LPG and DME laminar flame speed by ionization current method in a constant volume bomb. combustion.org.uk

[12] Fabiś P.: Pomiar ciśnienia indykowanego oraz drgań kadłuba silnika-koncepcja stanowiska badawczego. XXXII Ogólnopolskie Sympozjum Diagnostyka Maszyn, Węgierska Górka 2005.

[13] Flekiewicz M., Kubica G., Wilk K.: The analysis of heat release process in SI engine fed on natural gas and methane-hydrogen blends. SAITS - FISITA, 12th EAEC European Automotive Congress, Bratislava 2009.

[14] Campbell M., Wyszyński Ł.P., Stone R.: Combustion of LPG in a spark-ignition engine. SAE Paper 2004-01-0974.

[15] Van Mierlo J., Vereecken G., Maggetto G., Farrel V., Meyer S., Hecq W.: Comparison of the environmental damage caused by vehicles with different alternative fuels and drivetrains in a Brusells context. J. Automotive Eng. Proc. IMechE. Part D, vol. 217 no D7, pp. 583-594.

[16] DME handbook. Japan DME Forum. 2006 and 2012.

[17] Heywood J.B.: Internal combustion engines fundamentals. McGraw-Hill. New York 1998.

[18] Rogers D.R.: Engine combustion: pressure measurement and analysis. SAE International 2010.

[19] Changwei Ji, Chen Liang, Shuofeng Wang: Investigation on combustion and emissions of DME-gasoline mixtures in a spark-ignition engine. Fuel, vol. 90, 2011. p. 1133-1138.

Grzegorz Kubica, DEng. - doctor in the Faculty of Transport at Silesian University of Technology.

Dr inż. Grzegorz Kubica - adiunkt na Wydziale Transportu Politechniki Śląskiej.

e-mail: grzegorz.kubica@polsl.pl

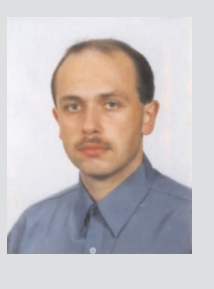

